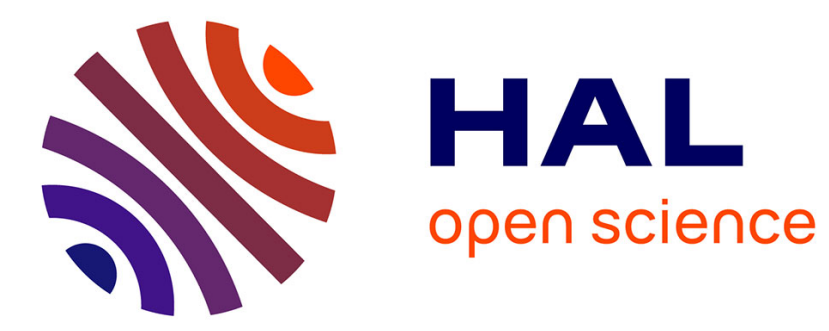

\title{
Opinion of the Scientific Committee on Consumer Safety (SCCS) - Final version of the opinion on Phenoxyethanol in cosmetic products
}

Werner Lilienblum

\section{- To cite this version:}

Werner Lilienblum. Opinion of the Scientific Committee on Consumer Safety (SCCS) - Final version of the opinion on Phenoxyethanol in cosmetic products. Regulatory Toxicology and Pharmacology, 2016, 82, pp.156. 10.1016/j.yrtph.2016.11.007 . hal-01598071

\section{HAL Id: hal-01598071 \\ https://hal.science/hal-01598071}

Submitted on 5 Feb 2019

HAL is a multi-disciplinary open access archive for the deposit and dissemination of scientific research documents, whether they are published or not. The documents may come from teaching and research institutions in France or abroad, or from public or private research centers.
L'archive ouverte pluridisciplinaire HAL, est destinée au dépôt et à la diffusion de documents scientifiques de niveau recherche, publiés ou non, émanant des établissements d'enseignement et de recherche français ou étrangers, des laboratoires publics ou privés. 
Commentary

\title{
Opinion of the Scientific Committee on Consumer Safety (SCCS) - Final version of the opinion on Phenoxyethanol in cosmetic products
}

\author{
Scientific Committee on Consumer Safety (SCCS) ${ }^{\mathrm{a},}$ * , Werner Lilienblum ${ }^{1}$ \\ a SCCS Secretariat at the European Commission, Directorate General for Health and Food Safety, 11, rue E. Ruppert, L-2920, Luxembourg
}

\section{A R T I C L E I N F O}

\section{Article history:}

Received 31 October 2016

Accepted 1 November 2016

Available online 4 November 2016

\section{Keywords}

SCCS

Scientific opinion

Phenoxyethanol

Regulation $1223 / 2009$

CAS no. 122-99-6

EC no. 204-589-7

\begin{abstract}
A B S T R A C T
The SCCS considers 2-phenoxyethanol safe for use as a preservative with a maximum concentration of $1.0 \%$, taking into account the information provided.

The toxicokinetics default factor of 4.0 can be reduced to 1.0 yielding a minimum Margin of Safety (MoS) of 25 instead of 100 for the safety assessment of 2-phenoxyethanol.

Therefore, the MoS of about 50 for children also covers this specific age group who might be higher exposed to 2-phenoxyethanol than adults.

This Opinion does not take into account exposure from sources other than cosmetics.
\end{abstract}

๑) 2016 Elsevier Inc. All rights reserved.
Phenoxyethanol CAS n. 122-99-6 as preservative is regulated in Annex V/29 of the Cosmetics Regulation (EC) n. 1223/2009.

According to the Cosmetics Regulation (EC) n.1223/2009 Phenoxyethanol is authorized as a preservative in cosmetic formulations at a maximum concentration of $1.0 \%$.

In September 2012, the Commission received a risk assessment submitted by the French Agency ANSM (Agence nationale de sécurité des médicaments et des produits de santé) which rose concerns about the use of Phenoxyethanol as preservatives in cosmetic products.

The ANSM report (Evaluation du risque lié à l'utilisation du phénoxyéthanol dans les produits cosmétiques) concludes that the maximum authorized concentration (currently of $1 \%$ ) of Phenoxyethanol for use as a preservative should be lowered to $0.4 \%$ in cosmetic products for children less than three years. In addition, Phenoxyethanol should not be used in cosmetic products intended for their nappy area. The Commission received information from other member States which raised similar concern on the use of Phenoxyethanol, in particular on children.

In December 2013, in response to a call for data on

\footnotetext{
* Corresponding author. (Authors of the Opinion SCCS members: Dr. U. Bernauer, Dr. L. Bodin, Dr. L. Celleno, Prof. Q. Chaudhry, Prof. P.J. Coenraads (Chair), Prof. M. Dusinska, Prof. J. Duus-Johansen, Dr. E. Ezendam, Dr. E. Gaffet, Prof. C. L. Galli, Dr. B. Granum, Dr. E. Panteri, Prof. V. Rogiers, Dr. Ch. Rousselle, Dr. M. Stepnik, Prof. T. Vanhaecke, Dr. S. Wijnhoven - Former SCCS members: Prof. G. Degen, Dr. W. Lilienblum (rapporteur), Dr. E. Nielsen, Prof. T. Platzek Dr. J. van Benthem - External experts: Prof. A. Bernard, Prof. Prof. A.M. Giménez-Arnau, Dr. E. Mirkova).

E-mail address: SCCS@ec.europa.eu.

1 Rapporteur of the Opinion.
}

Phenoxyethanol by the Commission, Cosmetics Europe submitted a safety dossier in order to defend the current use of Phenoxyethanol as preservative in cosmetic formulations at a maximum concentration of $1.0 \%$.

In December 2014, additional information from Cosmetics Europe (Subm. II) was received by the Commission and in July 2015 the submission of data was complemented with a safety assessment tool, such as the physiologically based pharmacokinetic (PBPK) modelling, in order to provide a perspective on systemic exposure of phenoxyethanol in humans (absorption, distribution, metabolism and excretion).

The SCCS considers 2-phenoxyethanol safe for use as a preservative with a maximum concentration of $1.0 \%$, taking into account the information provided.

The toxicokinetics default factor of 4.0 can be reduced to 1.0 yielding a minimum Margin of Safety (MoS) of 25 instead of 100 for the safety assessment of 2-phenoxyethanol.

Therefore, the MoS of about 50 for children also covers this specific age group who might be higher exposed to 2-phenoxyethanol than adults.

This Opinion does not take into account exposure from sources other than cosmetics.

\section{Appendix A. Supplementary data}

Supplementary data related to this article can be found at http:// dx.doi.org/10.1016/j.yrtph.2016.11.007. 